\title{
PENGEMBANGAN BAHAN AJAR BERBASIS ETNOMATEMATIKA PADA MATERI TRANSFORMASI GEOMETRI
}

\author{
Rani Nurmaya ${ }^{1 *}$, Reni Herawati ${ }^{2}$, Nani Ratnaningsih ${ }^{3}$ \\ 1,2,3 Universitas Siliwangi, Tasikmalaya, Indonesia \\ *raninrmy99@gmail.com
}

Diterima: 26 Januari 2021 Disetujui: 26 April 2021 Dipublikasikan: 30 April 2021

\begin{abstract}
ABSTRAK
Penelitian ini bertujuan untuk memperoleh suatu produk berupa bahan ajar matematika berbasis etnomatematika pada materi transformasi geometri. Penelitian ini merupakan penelitian pengembangan yang menggunakan desain ADDIE ( Analysis, Design, Develop, Implementasion, and Evaluate). Uji coba di lapangan bahan ajar yang telah disusun dilakukan dengan diserahkan kepada ahli media dengan menyertakan lembar penilaian validator dalam penelitian ini adalah guru pengampu mata pelajaran matematika SMP Muhammadiyah Kawali. Pengumpulan data menggunakan lembar validasi untuk menentukan validasi bahan ajar, kisi-kisi, dan instrumen untuk menentukan kelayakan bahan ajar yang kemudian dianalisis kevalidan bahan ajar yang dikembangan diperoleh dari data lembar validasi yang diisi oleh para ahli. Hasil penelitian ini adalah menghasilkan bahan ajar berbasis etnomatematika transformasi geometri yang dikembangkan valid digunakan dalam pembelajaran.
\end{abstract}

Kata kunci: pengembangan, etnomatematika, transformasi geometri

\section{ABSTRACT}

This study aims to obtain a product in the form of ethnomathematics-based mathematics teaching materials on geometric transformation materials. This research is development research that uses the ADDIE (Analysis, Design, Develop, Implementation, and Evaluate) design. Field trials of teaching materials that have been compiled were carried out by submitting to media experts by including assessment sheets, the validators in this study were teachers of junior high school Muhammadiyah Kawali subjects. Collecting data using validation sheets to determine the validation of teaching materials, grids, and instruments to determine the feasibility of teaching materials, which are then analyzed the validity of the teaching materials being developed obtained from validation sheet data filled out by experts. The results of this study are to produce teaching materials based on geometric transformation ethnomathematics that are developed suitable for use in learning.

Keywords: development, ethnomatematics, geometric transformation

\section{Pendahuluan}

Salah satu mata pelajaran yang mempunyai peranan penting dalam dunia pendidikan yaitu matematika. Matematika diajarkan di sekolah mulai dari Sekolah Dasar sampai Sekolah Menengah Atas. Namun, siswa tetap selalu merasa kesulitan dalam memahami konsep matematika yang diajarkan oleh gurunya. Padahal jika kita sadari, dalam kehidupan sehari-hari kita tidak pernah terlepas dari matematika. Pentingnya konteks kehidupan yang nyata sebagai alat dan sumber pembelajaran yang dikemukakan oleh (Johnson, 2002), bahwa sebagian besar siswa mengalami kesulitan mengaplikasikan matematika dalam kehidupan sehari-hari yang disebabkan pembelajaran matematika yang dikembangkan oleh gurunya sebatas menghafal rumus dan sedikit memahami konsep. Hal ini menjadi penyebab awal sulitnya siswa dalam belajar matematika, yakni matematika dirasakan kurang bermakna (Dahlan \& Permatasari, 2018).

Matematika ternyata selalu tidak lepas dalam kehidupan sehari-hari. Bahkan dalam motif batik pun dapat ditemukan konsep matematika. Menurut (Dahlan \& Permatasari, 2018), etnomatematika merupakan suatu pengetahuan yang mengaitkan matematika dengan unsur budaya. Wujud keterkaitannya dapat diperlihatkan dalam aspek penerapan konsep-konsep matematika dalam suatu budaya (terkadang 


\section{Range: Jurnal Pendidikan Matematika Vol. 2 No. 2 Tahun 2021 Rani Nurmaya, dkk}

street mathematics), serta cara mengajarkan matematika yang disesuaikan dengan budaya lokal dan keunikan karakter siswa sehingga diharapkan siswa dapat "membaur" dengan konsep matematika yang diajarkan dan merasa bahwa matematika adalah bagian dari budaya mereka.

Budaya bangsa Indonesia sangat beragam, salah satunya adalah di Tasikmalaya. Ada banyak kebudayaan di Tasikmalaya, diantaranya yaitu kebudayaa Kampung Naga, payung geulis, kelom geulis, kerajinan Rajapolah, kerajinan Mendong dan yang paling menarik batik khas Tasikmalaya. Batik merupakan karya seni warisan turun-temurun budaya Indonesia. Setiap daerah mempunyai motif batik dengan ciri khas dan keunikannya masing-masing. Sebagai penerus bangsa, perlu melestarikan budaya kita sendiri dengan lebih mengenal motif batik. Dalam motif batik terdapat konsep matematika yaitu konsep Transformasi Geometri.

Berdasarkan penelitian sebelumnya oleh (Fitriyah et al., 2018) dengan judul "Bahan Ajar Transformasi Geometri Berbasis Discovery Learning melalui Pendekatan Etnomatematika"hasil penelitiannya menyatakan bahan ajar yang diterapkan masuk ke dalam kriteria sangat praktis yang ditunjukkan dengan nilai kepraktisan $84,5 \%$, artinya bahan ajar yang dikembangan dikatakan efektif untuk digunakan dalam pembelajaran. Guru harus mampu menentukan metode dan model pembelajaran yang tepat sesuai kemampuan siswa yang beragam, sehingga materi pembelajaran dapat tersampaikan secara maksimal (Aprilia et al., 2019). Oleh karena itu, seorang guru profesional harus mampu mendesain bahan ajar yang menarik dan efektif digunakan dalam pembelajaran matematika, agar siswa pun mudah memahami materi. Salah satunya dengan menggunakan pendekatan etnomatematika.

Menurut Jarnawi, menyatakan bahwa etnomatematika pertama kali dicetuskan oleh D'Ambrosio (dalam (Rosa \& Orey, 2011)), "the mathematical practices of identifiable curtural groups and may be regarded as the study of mathematical ideas found in any culture". Dimana etnomatematika mempelajari matematika yang ditemukan pada suatu budaya atau kelompok masyarakat. Dalam setiap budaya yang dimiliki oleh suatu kelompok masyarakat, sering tidak disadari adanya kaitan dengan konsep matematika.Unsur budaya dikaji untuk diintegrasikan ke dalam pembelajaran lebih baik jika dilakukan mulai dari budaya yang ada di lingkungan sekitar sesuai dengan prinsip pembelajaran kontekstual, dimana pembelajaran memanfaatkan hal-hal yang ada di lingkungan sekitar (Ayuningtyas \& Setiana, 2018). Salah satunya di Kota Tasikmalaya, terdapat banyak sekali kebudayaan yang perlu diketahui siswa, seperti batik, kerajinan rajapolah, kerajinan mendong, payung geulis, kelom geulis, dan lain-lain.

Bahan ajar merupakan perangkat pembelajaran berisi informasi untuk mencapai tujuan pembelajaran, baik berbentuk cetak maupun elektronik. (Cahyadi, 2019) berpendapat bahwa bahan ajar adalah perangkat yang berisikan informasi baik cetak maupun elektronik yang digunakan oleh siswa untuk mencapai tujuan pembelajaran dengan mencakup materi-materi ajar untuk tujuan umum penbelajaran dan beberapa matemri tambahan sebagai pengayaan maupun untuk remedial. Bahan ajar akan baik jika dirancang dengan memperhatikan pola pikir siswa, sehingga dapat membantu guru dan siswa selama pembelajaran dengan memperhatikan kurikulum yang digunakan (Suprana \& Farida, 2019).

Transformasi geometri adalah sebuah perubahan posisi atau perpindahan dari suatu posisi awal $(x, y)$ ke posisi lain $\left(x^{\prime}, y^{\prime}\right)$. Jenis-jenis transformasi geometri terdiri dari translasi, refleksi, rotasi dan dilatasi. Materi transformasi geometri ini dipelajari di kelas IX Sekolah Menengah Pertama. Berdasarkan konsep Geometri untuk sekolah menengah pertama pada kebudayaan Tasikmalaya, dapat dijadikan alternatif pembelajaran transformasi geometri pada sekolah menengah pertama, seperti pada materi translasi, dilatasi, refleksi dan rotasi.

Berdasarkan uraian di atas, maka diperlukan suatu riset pengembangan bahan ajar matematika berbasis etnomatematika khususnya pada materi transformasi geometri. Diharapkan dengan penggunaan bahan ajar berbasis etnomatematika dapat memudahkan siswa dalam memahami materi.

\section{Metode Penelitian}

Metode penelitian dalam penelitian ini adalah Reserach and Development. Penelitian ini bertujuan untuk memperoleh suatu produk berupa bahan ajar matematika berbasis etnomatematika pada 


\section{Range: Jurnal Pendidikan Matematika Vol. 2 No. 2 Tahun 2021 Rani Nurmaya, dkk}

materi Transformasi Geometri. Dalam implementasinya, penelitian ini menggunakan desain ADDIE (Analysis, Design, Develop, Implementasion, and Ecaluate). Penelitian ini hanya sampai tahap uji vadilasi oleh validator. Adapun kegiatan yang dikembangkan dengan tahapan tersebut adalah sebagai berikut.

Tahap 1 Analysis. Kegiatan analisis dilakukan untuk memperoleh gambaran tentang kebudayaan motif kain batik di Indonesia, telaah kurikulum matematika dan materi yang dibahas. Pada tahap ini dilakukan analisis secara studi literatur, yaitu pengumpulan data pustaka, membaca, mencatat, serta mengolah bahan penelitian. Analisis kebutuhan peserta didik dilakukan dengan kajian pustaka bahwa belum ada inovasi yang menggunakan bahan ajar dengan desain yang menarik untuk mempermudah pemahaman siswa dan siswa tertarik untuk belajar. Analisis kurikulum digunakan untuk mengetahui kurikulum yang diterapkan di sekolah, yaitu menggunakan kurikulum 2013. Karena dalam implementasinya menjadikan seni dan budaya sebagai tolak ukur, maka peneliti mengambil objek berbasis etnomatematika sebagai konten pembelajaran. Berdasarkan kurikulum 2013 mata pelajaran matematika kelas IX, salah satu materi yang dipelajari adalah transformasi geometri, yang meliputi translasi, refleksi, rotasi dan dilatasi. Berkaitan hal tersebut, peneliti menggunakan objek etnomatematika berupa budaya Tasikmalaya yang memiliki potensi untuk dijadikan konten pembelajaran.

Tahap 2 Design. Tahap ini merupakan pengkajian model bahan ajar berbasis etnomatematika., diantaranya yaitu penyusunan format bahan ajar; pemilihan pendekatan penyajian yang digunakan didasarkan pada pendekatan dan pembelajaran yang direkomendasikan kurikulum 2013, yakni menggunakan pendekatan saintifik; akhir tahap ini diperolehnya bahan ajar berbasis etnomatematika dalam bentuk cetak.

Tahap 3 Development. Pada tahap ini dilakukan uji kelayakan atau uji validitas, diuji atau dinilai oleh orang yang berkompeten dalam bidang produk/ instrumen yang dikembangkan atau orang yang ahli dalam bidang tersebut. Bahan ajar yang telah disusun diserahkan kepada ahli media dengan menyertakan lembar penilaian.

Dalam penelitian dilakukan analisis kevalidan bahan ajar yang dikembangan diperoleh dari data lembar validasi yang diisi oleh para ahli. Total skor yang diperoleh dari instrumen dianalisis dengan cara konversi menggunakan rumus:

$$
p=\frac{\sum x_{i}-\min }{\operatorname{maks}-\min } \times 100 \%
$$

Dan diinterpretasikan menggunakan tabel tingkat kepraktisan dan kevalidan bahan ajar yang diadaptasi dari tabel konversi menurut (Arikunto, 2010) sebagai berikut.

Tabel 1. Tingkat Kepraktisan dan Kevalidan Bahan Ajar

\begin{tabular}{ccl}
\hline Tingkat Pencapaian & Kriteria Valid & Kriteria Praktis \\
\hline $80-100$ & Sangat Valid & Sangat Praktis \\
$66-79$ & Valid & Praktis \\
$56-65$ & Cukup Valid & Cukup Praktis \\
$40-55$ & Kurang Valid & Kurang Praktis \\
$0-39$ & Sangat Kurang & Sangat Kurang \\
\hline
\end{tabular}

\section{Hasil Penelitian dan Pembahasan}

Hasil penelitian pengembangan bahan ajar yang diperoleh dari hasil validasi ahli yaitu guru mata pelajaran matematika terhadap 4 aspek penilaian yaitu aspek kelayakan isi, aspek kelayakan penyajian, aspek kelayakan bahasa dan aspek kontekstual. Hasil tersebut kemudian dianalisis dengan mempertimbangkan saran dan komentar dari validator yang dijadikan acuan untuk bahan ajar yang telah dikembangkan. Adapun kategori skor adalah sebagai berikut: "1" berarti sangat kurang, "2" berarti 


\section{Range: Jurnal Pendidikan Matematika Vol. 2 No. 2 Tahun 2021 Rani Nurmaya, dkk}

kurang, "3" berarti baik, "4" berarti sangat baik. Hasil rekapitulasi penilaian validator secara singkat dapat dilihat pada Tabel 2 .

Tabel 2. Hasil Validasi Bahan Ajar

\begin{tabular}{lcc}
\hline \multicolumn{1}{c}{ Aspek Penilaian } & Skor $(\%)$ & Interpretasi \\
\hline Kelayakan isi & 82 & Sangat Valid \\
Kelayakan penyajian & 75 & Valid \\
Kelayakan bahasa & 78 & Valid \\
Kontekstual & 81 & Sangat Valid \\
Mean & 79 & Valid \\
\hline
\end{tabular}

Berdasarkan Tabel 2 terlihat bahwa pencapaian total skor tingkat kelayakan sebesar 79 dalam kriteria baik dan semua aspek penilaian dalam kriteria sangat baik dan baik. Oleh karena itu, bahan ajar ini valid dan layak digunakan untuk pembelajaran. Dalam angket validasi pun diajukan beberapa pertanyaan untuk menjelaskan hasil validasi tersebut, bahwa bahan ajar berbasis etnomatematika ini layak digunakan dan dapat membantu siswa dalam memahami materi Transformasi Geometri karena setiap pembahasan berkaitan dengan kehidupan sehari-hari. Pada bahan ajar ini juga terdapat kelebihan yaitu materi yang disajikan dalam bentuk gambar yang menarik dan mengaitkan materi terhadap unsur budaya di Tasikmalaya sehingga diharapkan akan memicu rasa ingin tahu siswa saat pembelajaran. Adapun saran pengembangan pada Bahan Ajar ini dari validator yaitu pada setiap pembahasan materi ditambahkan pengantar materi dan penjelasannya, serta lebih banyak menyajikan contoh soal.

Berdasarkan hasil penelitian, diperoleh penilaian bahan ajar yang dikembangkan yakni $79 \%$ valid, maka bahan ajar berbasis etnomatematika pada materi Transformasi Geometri ini masuk kategori valid. Bahan ajar yang dikembang ini membahas materi transformasi geometri yang dikaitkan dengan penerapannya pada kebudayaan Tasikmalaya, seperti motif batik, payung geulis, kampung naga dan sebagainya.

Karakteristik bahan ajar yang dikembangkan mengikuti standar buku ajar yang baik diantaranya adalah bahan ajar berbentuk buku dengan ukuran B5. Materi dalam bahan ajar terdiri dari dua Kompetensi Dasar (KD), yaitu materi tentang transformasi geometri, serta kesebangunan dan kekongeruenan. Bahan ajar ini memiliki ketebalan 50 halaman serta isi materi dengan langkah pembelajaran pendekatan saintifik. Langkah-langkah saintifik tersebut adalah mengamati, menanya, mengumpulkan informasi, mencoba, dan mengkomunikasikan. Ilustrasi gambar dalam bahan ajar dikaitkan dengan budaya khas Tasikmalaya (etnomatematika) seperti motif batik, payung geulis, Kampung Naga, kerajinan mendongan, kerajinan rajapolah, dan budaya khas Tasikmalaya lainnya. Selain itu, terdapat latihan soal pada setiap sub bab materi disertai kunci jawaban di akhir bahan ajar.

Adapun desain bahan ajar berbasis etnomatematika seperti pada Gambar 1 dan Gambar 2. Gambar 1 merupakan desain bagian depan (cover) bahan ajar berbasis etnomatematika yang terdiri atas judul, tingkat pendidikan dan kelas. 


\section{Range: Jurnal Pendidikan Matematika Vol. 2 No. 2 Tahun 2021 Rani Nurmaya, dkk}

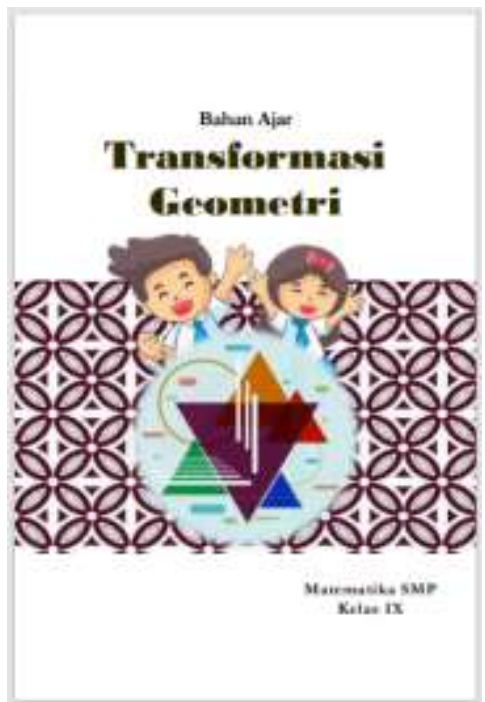

Gambar 1. Bagian cover

Pada Gambar 2 ini merupakan desain bagian isi dari bahan ajar berbasis etnomatematika pada materi Transformasi Geometri, terdapat judul materi yang akan dipelajari dan kegiatan pembelajaran siswa yaitu bagian kegiatan mengamati materi yang akan dipelajari.

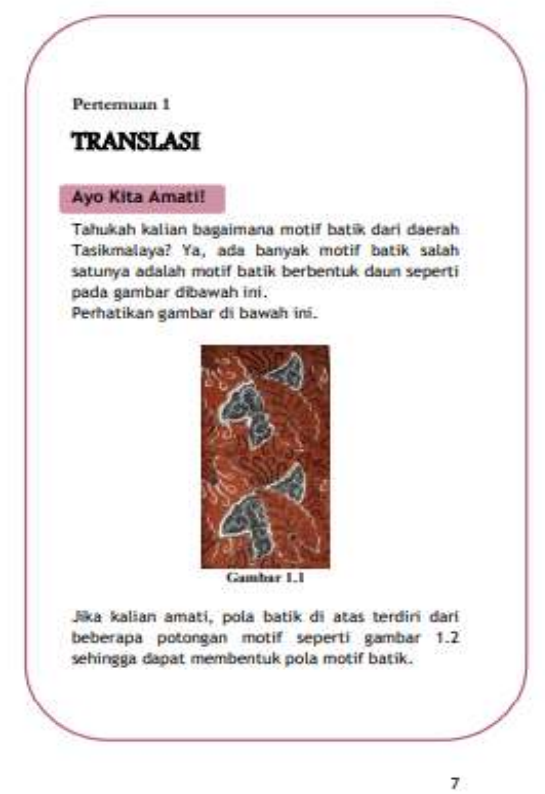

Gambar 2. Bagian mengamati

Bahan ajar berbasis etnomatematika memberikan tampilan yang berbeda sehingga siswa dapat lebih termotivasi dan semangat belajar matematika. Sejalan dengan penelitian Fitriyah (2018) yang berjudul Bahan Ajar Transformasi Geometri Berbasis Discovery Learning melalui Pendekatan Etnomatematika, bahwa pengembangan bahan ajar berbasis etnomatematika dapat dengan mudah memberikan pemahaman kepada siswa tentang materi yang disampaikan, juga dapat mengenal kebudayaan yang ada kaitannya dengan konsep matematika. Siswa juga dapat lebih mudah memahami konsep dibandingkan dengan menghafal rumus. 


\section{Range: Jurnal Pendidikan Matematika Vol. 2 No. 2 Tahun 2021 Rani Nurmaya, dkk}

Dalam Kurikulum 2013, unsur budaya adalah salah satu hal yang ditekankan pada pencapaian KI 3. Sebagaimana pandangan dari (Wahyuni et al., 2013) yang berpandangan bahwa pembelajaran matematika memerlukan suatu pendekatan agar dapat memberikan pembelajaran yang efektif dan siswa mampu menguasai konten atau materi yang diajarkan serta menerapkannya dalam memecahkan masalah. Bahan ajar ini mengangkat budaya Tasikmalaya, Jawa Barat. Hal ini mengacu pada sasaran pengguna produk yaitu siswa Sekolah Menengah Pertama di wilayah Tasikmalaya, Jawa Barat.

Pengembangan bahan ajar ini menempatkan budaya pada posisi penting dalam pembelajaran matematika. Untuk melihat validitas isi produk yang telah dikembangkan, tahapan validasi dalam penelitian ini mendukung penelitian-penelitian yang telah dilakukan yang juga menggunakan cara validasi terhadap ahli. Adapun penelitian-penelitian tersebut yaitu penelitian yang dilakukan oleh (Utami et al., 2018) yang mengangkat judul penelitian pengembangan e-modul berbasis etnomatematika untuk meningkatkan kemampuan pemecahan masalah dan penelitian (Aprilia et al., 2019) yang berjudul etnomatematika pada permainan tradisional engklek beserta alatnya sebagai bahan ajar.

Menurut (Suhartini \& Martyanti, 2017), menyatakan bahwa kemampuan berpikir siswa dalam proses pembelajaran dengan menggunakan materi geometri berbasis etnomatematika dapat meningkat. Sehingga dengan mengembangkan bahan ajar berbasis etnomatematika pada materi transformasi geometri diharapkan dapat memudahkan siswa dalam memahami materi. Selain membantu dalam memahami materi, juga membantu mengenalkan budaya yang ada di lingkungan sekitar. (Fitriatien, 2016) juga menyatakan bahwa nilai-nilai sosio-kultur-budaya tidak terlepas dari ilmu matematika yang dijembatani oleh etnomatematika, sehingga pembelajaran berbasis etnomatematika sebagai upaya perbaikan dalam memperbaiki kualitas pembelajaran matematika.

\section{Kesimpulan}

Simpulan yang diperoleh dalam penelitian ini adalah dihasilkan bahan ajar transformasi geometri yang berbasis etnomatematika yang dikembangkan dinyatakan valid dalam kriteria sangat baik dan baik sehingga dapat digunakan, meskipun dengan adanya revisi.

\section{Saran}

Saran untuk peneliti selanjutnya, dapat lebih mengembangkan bahan ajar berbasis etnomatematika dengan menambah lebih banyak permasalahan dan contoh soal. Agar lebih menarik dapat dikembangkan dengan berbasis elektronik atau dibuat dalam bentuk media interaktif.

\section{Ucapan Terima Kasih}

Penulis ucapkan terima kasih kepada Allah SWT., atas rahmat dan hidayah-Nya penulis dapat menyelesaikan penelitian ini. Tak lupa kepada dosen pembimbing mata kuliah Metodologi Penelitian Pengembangan yang telah membimbing selama proses pengembangan penelitian. Kepada guru pengampu mata pelajaran matematika SMP Muhammadiyah Kawali yang bersedia menjadi validator sehingga dapat terselesaikannya penelitian ini. Teman-teman seperjuangan yang selalu memotivasi dan memberikan semangat kepada penulis sehingga dapat selesai tepat waktu.

\section{Daftar Pustaka}

Aprilia, E. D., Trapsilasiwi, D., \& Setiawan, T. B. (2019). Etnomatematika pada Permainan Tradisional Engklek Beserta Alatnya sebagai Bahan Ajar. Kadikma, 10(1), 85-94. https://doi.org/https://doi.org/10.19184/kdma.v10i1.11735

Arikunto, S. (2010). Prosedur Penelitian Suatu Pendekatan Praktik. Rineka Cipta.

Ayuningtyas, D. A., \& Setiana, D. S. (2018). Bahan Ajar Matematika Berbasis Etnomatematika Kraton 


\section{Range: Jurnal Pendidikan Matematika Vol. 2 No. 2 Tahun 2021 Rani Nurmaya, dkk}

Yogyakarta. Prosiding Seminar Nasional Matematika Dan Pendidikan Matematika, "Integrasi Budaya, Psikologi, Dan Teknologi Dalam Membangun Pendidikan Karakter Melalui Matematika Dan Pembelajarannya.

Cahyadi, R. A. H. (2019). Pengembangan Bahan Ajar Berbasis ADDIE Model. Halaqa: Islamic Education Journal. https://doi.org/10.21070/halaqa.v3i1.2124

Dahlan, J. A., \& Permatasari, D. (2018). Pengembangan Bahan Ajar Berbasis Etnomatematika dalam Pembelajaran Matematika Sekolah Menengah Pertama. JNPM (Jurnal Nasional Pendidikan Matematika), 2(1), 133.

Fitriatien, S. R. (2016). Pembelajaran Berbasis Etnomatematika. Seminar Nasional Pendidikan Matematika Ikatan Alumni S3 Pendidikan Matematika.

Fitriyah, D. N., Santoso, H., \& Suryadinata, N. (2018). Bahan Ajar Transformasi Geometri Berbasis Discovery Learning melalui Pendekatan Etnomatematika. Jurnal Elemen, 4(2), 145-158.

Johnson, E. B. (2002). Contextual teaching and learning. Thousand Oak, California: Sage Publication Company.

Rosa, M., \& Orey, D. C. (2011). Ethnomathematics: the cultural aspects of the mathematics. Revista Latinoamericana de Etnomatematika, 4(2), 35-36.

Suhartini, \& Martyanti, A. (2017). Meningkatkan Kemampuan Berpikir Kritis pada Pembelajaran Geometri Berbasis Etnomatematika. Jurnal Gantang, 2(2), 105-111. https://doi.org/10.31629/jg.v2i2.198

Suprana, E., \& Farida, N. (2019). Pengembangan Bahan Ajar Matematika Berbasis Etnomatematika pada Materi Geometri Transformasi. Limacon: Journal of Mathematics Education, 1(1), 1-7.

Utami, R. E., Nugroho, A. A., Dwijayanti, I., \& Sukarno, A. (2018). Pengembangan E-Modul Berbasis Etnomatematika untuk Meningkatkan Kemampuan Pemecahan Masalah. Jurnal Nasional Pendidikan Matematika, 2(2), 268-283.

Wahyuni, A., Tias, A. A. W., \& Sani, B. (2013). Peran Etnomatematika dalam Membangun Karakter Bangsa. Prosiding Seminar Nasional Matematika Dan Pendidikan Matematika FMIPA UNY. 